\title{
Designing Motorcycle Safety System Using Fingerprint Sensor, SMS Gateway, and GPS Tracker Based on ATMega328
}

\author{
Marhaposan Situmorang $^{1^{*}}$ and Esra Fitri Yanti Aritonang ${ }^{2}$ \\ ${ }^{1,2}$ Department of Physics, Faculty of Mathematics and Natural Science, Universitas Sumatera Utara, \\ Medan 20155, Indonesia
}

\begin{abstract}
A motorcycle security system has been designed using an ATMega328 microcontroller by applying fingerprint, SMS and GPS. The system consists of a GPS Module and a SIM Module. The system is designed to find the position of a stolen motorcycle via a Google Maps and create a security system on a motorcycle that uses a fingerprint sensor as a substitute for the key to turn on and turn off the motorcycle engine. ATMega328 is used as a processor, with additional GPS, GSM SIM 8000I, relay and buzzer. When a theft occurs, the system will send an SMS contained Google Maps link to the owner of the motorcycle. The results of the system design are expected to minimize the crime rate in motor vehicle theft cases.
\end{abstract}

Keyword: ATMega328, fingerprint sensor, SMS gateway, GPS tracker, SIM module.

Received 5 February 2021 | Revised [19 February 2021] | Accepted [25 February 2021]

\section{Introduction}

Advances in technology and the development of human civilization from time to time, the need for human interests is increasing. This has a negative impact because it will increase the likelihood of crime. The more technology develops, the more criminal acts, including theft. Motor vehicle theft, known as curanmor, occupies the top place for criminal acts. This case seriously disturbed security and public order, and has occurred in every region for a long time [1]. The manufacturer only provides basic safeguards such as locking the handlebar and innovation of the ignition only. The work system of security like this cannot be relied on by motorcycle owners [2]. Therefore, a safety system must be made in motorized vehicles to avoid things that are not desirable [3].

Motor vehicle theft perpetrators have various experiences and modes. The mode often used by motorcycle thieves is to use the $\mathrm{T}$ key to break into the ignition of a motorcycle [4]. Several ways to secure yourself from the crime of robbery that is often done include preparing a

\footnotetext{
*Corresponding author at: Jalan Biolteknologi no.1 Medan, 20155, Indonesia

E-mail address: marhaposan@usu.ac.id
} 
cellphone to make emergency calls to the police station [5]. SMS Gateway is a type of two-way sms service, which combines the sending of information from a computer device on a network owned by a cellular operator [6]. Fingerprint or fingerprint sensor is a technology development that has high enough security where it can only be accessed by people whose fingerprints have been inputted into the fingerprint [7].

In cases of theft that often occur, motorized vehicles are taken away by thieves, therefore a tracking system is needed. This study uses a GPS (Global Positioning System) system which is used to determine the position of the coordinate points and determine the distance of vehicle movement when parked [8]. A vehicle tracking system is a series of systems installed on a vehicle that can be tracked by modern vehicle owners, generally using a GPS device to determine the location of the vehicle. GPS is a satellite-based navigation system that can show location and time information in all weather conditions anywhere on the earth's surface as long as it has coverage [9].

A system is a collection or group or any physical component that is interconnected with one another and works together in harmony to achieve certain goals. A security system is a system used to provide a sense of freedom from danger, not to feel afraid, anxious, or anxious about the valuables that are left behind. The security system can identify the possibility of theft or other crimes that have an impact on losses [10]. In fleet management, this system is very helpful in avoiding stealing vehicle use or using lanes / routes that are permitted by the fleet owner [11].

Microcontroller is a tool that performs limited local functions. The microcontroller has the potential to be the brain used to make decisions in the event of a condition such as car theft. The microcontroller is equipped with a theft sensor device that detects theft, then the microcontroller can receive the information and then send a message about the location of the car [12]. ATMega328 is an output microcontroller from atmel which has a RISC (Reduce Instruction Set Computer) architecture. The ATMega328 microcontroller has a Harvard architecture, which separates memory for program code and memory for data so that it can maximize work [13]. The microcontroller used is Arduino, Arduino is an open source electronic circuit board or electronic kit in which there is the main component of a microcontroller chip with the AVR (Automatic Voltage Regulator) type from the Atmel company. Precise Point Positioning is a method used to obtain the position points generated from the system GPS data processing is done in real time [14-17]. GPS is a system for determining the location on the earth's surface with the help of satellite signal synchronization. GPS Tracker or often referred to as GPS Tracking is AVL technology. (Automated Vehicle Locater ) which allows the user to track the position of the vehicle. GPS Tracking utilizes a combination of GSM and GPS technology to determine the coordinates of an object and then translate it into a digital map [18-20]. 


\section{Methods}

\subsection{Block Diagram}

Figure 1 is a block diagram of a motorcycle security system based on ATMega328.

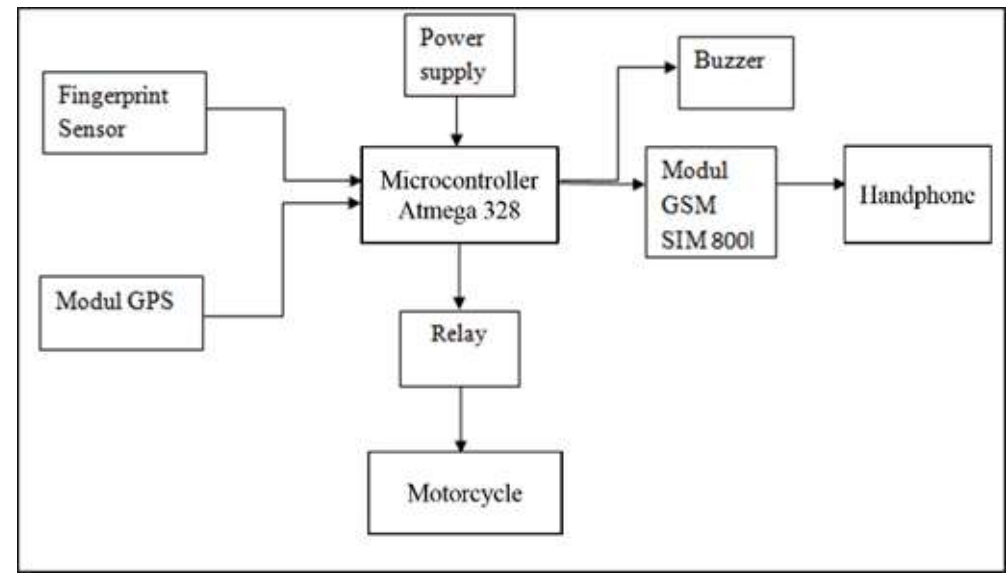

Figure 1. Block Diagram of The System

The Fingerprint Sensor functions to turn on and turn off two-wheeled vehicles where the owner has scanned a finger on the fingerprint sensor. The microcontroller functions as a system control that will send commands to the GSM SIM800I module. GSM SIM800I functions as an SMS sender to your handphone. If there is a fingerprint scan error 3 times, an alarm (buzzer) will sound. In case of theft, the GPS module will work with the help of a microcontroller which will then send a notification to the vehicle owner's cellphone. The owner can find out the whereabouts of the vehicle and can turn off the vehicle automatically via cellphone.

\subsection{Flowchart}

Figure 2 is a flowchart of a motorcycle security system based on ATMega328.

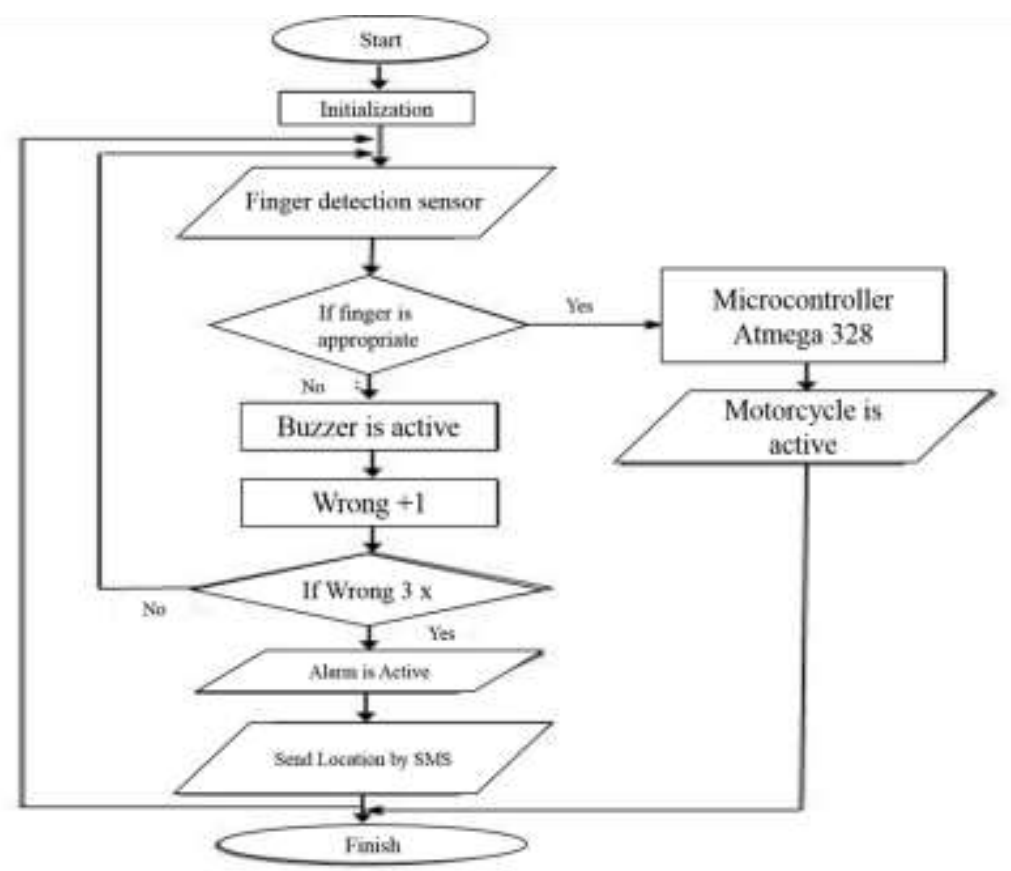

Figure 2. Flow Chart of Motorcycle Safety System 


\section{Result and Discussion}

\subsection{Testing Relay Starter}

Tests are carried out to find out whether the starter circuit can work properly. The test results can be seen in Table 1. 12V DC voltage source is connected to the NO relay and the starter is connected to COM and Ground. Testing is done by providing a $5 \mathrm{~V}$ DC input voltage from the microcontroller for testing the starter relay circuit. When the relay is active, the starter starts and the current from the voltage source will flow through NO and COM. However, when the relay is inactive, the starter dies.

Table 1. The Results of Testing the Starter Relay Circuit

\begin{tabular}{ccc}
\hline Voltage Relay & Condition At Starter & Starter Conditions \\
\hline Active & 11.95 & Live \\
Not active & 00.00 & Not Live \\
\hline
\end{tabular}

\subsection{Testing of Ignition Cable Relays}

Tests are carried out to determine whether the ignition cable relay circuit can work properly. The test results can be seen in Table 2. 12V DC voltage source is connected to the NC relay and the ignition cable is connected to COM and Ground. Testing is done by providing a 5V DC voltage input from the microcontroller. When the relay is in active condition, the ignition cable is disconnected and the vehicle engine will shut down. However, when the relay is inactive, the ignition cable is connected to the current from the voltage source and flows through the $\mathrm{NC}$ and COM.

Table 2. The Results of Testing Ignition Wires

\begin{tabular}{ccc}
\hline Relay Condition & $\begin{array}{c}\text { Voltage on the cable } \\
\text { Ignition Key (Volt) }\end{array}$ & Ignition Key Cable Condition \\
\hline Active & 00.00 & Disconnected \\
Not Active & 11.94 & Connected \\
\hline
\end{tabular}

\subsection{GSM Shield SIM 800 Module Testing}

The test was conducted to find out whether the GSM Shield SIM 800 Module circuit can work properly. The test is carried out by providing a $5 \mathrm{~V}$ DC input voltage and then connected to a microcontroller that has been given the program. The results of the test can be seen in Figure 3 . 


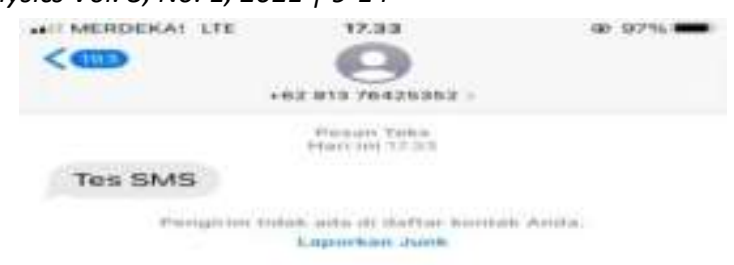

Figure 3. Testing GSM SIM 800 Module on the SMS User Display

\section{Conclusion}

A motorcycle security system using a fingerprint sensor, SMS gateway, and GPS tracker based on ATMega328 which is designed to work well. The system is in accordance with the planned concept. Can locate motorbikes with GPS tracking and send a motorbike location link to the vehicle owner's cellphone. Using a relay as a button that is controlled to start and stop the vehicle engine.

\section{REFERENCES}

[1] R. Soesilo, Kitab Undang-undang Hukum Pidana (KUHP) Serta Komentar-Komentarnya Lengkap Pasal Demi Pasal, Bogor: Politeia, 1998.

[2] H. Supriyono and A. D. N. Setyawan, "Perancangan Immobilizer Berbasis RFID untuk Sepeda Motor," Emitor: Jurnal Teknik Elektro, vol. 16, no. 2, pp. 69-73, 2016.

[3] D. K. Aji, "Sistem Pengaman Sepeda Motor dengan Arduino Berbasis Android," Undergraduate thesis, Universitas Muhammadiyah Surakarta, Surakarta, 2018.

[4] Suryamin, Perkembangan Jumlah Kendaraan Bermotor, 2018. Available from http://www.bps.go.id/. [Accessed: April 10, 2018].

[5] M. M. Thoyyib, "Sistem Keamanan Sepeda Motor dari Perampasan Menggunakan SMS dan GPS Berbasis Arduino Nano," Undergraduate thesis, Universtitas Negeri Yogyakarta, Yogyakarta, 2017.

[6] A. R. Febrianto, "Sistem Pengamanan Sepeda Motor Menggunakan SMS Gateway dan GPS," Undergraduate thesis, Politeknik Negeri Batam, Batam, 2017.

[7] M. Muhsin, Elektronika Digital Teori dan Soal Penyelesaian, Yogyakarta: Penerbit ANDI, 2004.

[8] Gusmanto, E. D. Marindani and B. W. Sanjaya, "Rancang Bangun Sistem Peringatan Dini dan Pelacakan pada Kendaraan Sepeda Motor dengan Menggunakan Mikrokontroller Arduino Nano," Jurnal Teknik Elektro Universitas Tanjungpura, vol. 2, no. 2, pp. 1-10, 2016.

[9] J. R. Oroh, E. Kendekallo, S. R. U. A. Sompie and J. O. Wuwung, "Rancang Bangun Sistem Keamanan Motor dengan Pengenalan Sidik Jari," e-Journal Teknik Elektro dan Komputer, vol. 3, no. 1, pp. 1-7, 2014.

[10] B. Suharjo, S. Falentino and S. Liawatimena, "Perancangan Sistem Keamanan Sepeda Motor dengan Sistem Sidik Jari," Jurnal Teknik Komputer, vol. 19, no. 1, pp. 17-27, 2011.

[11] S. P. Wijaya, Y. Christiyono and Sukiswo, "Alat Pelacak Lokasi Berbasis GPS Via Komunikasi Seluler," TRANSMISI, vol. 12, no. 2, pp. 82-86, 2010.

[12] S. Ma'arif, "Sistem Pelacak Mobil Berbasis Mikrokontroler dengan Pelaporan Melalui SMS," Undergraduate thesis, Universitas Islam Indonesia, Yogyakarta, 2016.

[13] Ferdynal, Mikrokontroler ATMega328, 2015. [serial online]. Available from https://documents.tips/documents/mikrokontroller-atmega-328.html. 
[Accessed: February 07, 2018].

[14] A. Pangestu, Sumardi and Sudjadi, "Perancangan Alat Pengaman dan Tracking Kendaraan Sepeda Motor dengan Menggunakan Mikrokontroller ATMega544PA," TRANSIENT, vol. 3, no. 4, pp. 433-441, 2014.

[15] L. Mervart, Z. Lukes, C. Rocken, and T. Iwabuchi, "Precise point positioning with ambiguity resolution in real-time." In Proceedings of the 21st International Technical Meeting of the Satellite Division of The Institute of Navigation (ION GNSS 2008 , pp. 397405, 2008, September.

[16] J. F. Zumberge, M. B. Heflin, D.C. Jefferson, M.M. Watkins, and F.H. Webb, "Precise point positioning for the efficient and robust analysis of GPS data from large networks" Journal of geophysical research: solid earth, vol. 102, no.B3, pp.5005-5017, 1997.

[17] Y. Gao, Y. Zhang, and K. Chen, "Development of a Real-Time Single-Frequency Precise Point Positioning System and Road Test Results", In Proceedings of the 19th International Technical Meeting of the Satellite Division of The Institute of Navigation (ION GNSS 2006), pp. 2297-2303, 2006, September.

[18] E. Afrianto, Pengenalan Alat Ukur GPS, 2012. Available from https://geodesiinfo.wordpress.com/2014/03/22/pengenalan-alat-ukur-gps/ [Accessed: January, 2016].

[19] S. Van der Spek, J. Van Schaick, P. De Bois, and R. De Haan, "Sensing human activity: GPS tracking", Sensors, vol. 9, no.4, pp.3033-3055, 2009.

[20] N. Chadil, A. Russameesawang, and P. Keeratiwintakorn, "Real-time tracking management system using GPS, GPRS and Google earth", In 2008 5th International Conference on Electrical Engineering/Electronics, Computer, Telecommunications and Information Technology, Vol. 1, pp. 393-396, 2008, May. 